\title{
Characteristics of Dew Formation and Distribution, and Its Contribution to the Surface Water Budget in a Semi-arid Region in China
}

\author{
Qiang Zhang • Sheng Wang • Fu-Lin Yang • \\ Ping Yue - Tong Yao • Wen-Yu Wang
}

Received: 8 October 2013 / Accepted: 25 August 2014 / Published online: 16 September 2014

(C) The Author(s) 2014. This article is published with open access at Springerlink.com

\begin{abstract}
Observations in the semi-arid Loess Plateau area of north-west China are utilized to reveal the characteristics and variations in the seasonal distribution of dewfall (frost) and the influence of micrometeorology, precipitation, and other weather conditions. Precipitation is the dominant water source in the Loess Plateau; however, non-rainfall water accounts for $13 \%$ of the total land-surface water source. Dew is the second largest non-rainfall component next only to soil adsorption water. Observations show that dew (frost) occurrence is likely to occur when an inversion occurs between the heights of 1 and $4 \mathrm{~m}$ with a temperature difference of $0.25 \mathrm{~K}$, surface wind speed of $1.5 \mathrm{~m} \mathrm{~s}^{-1}$, and surface relative humidity greater than $80 \%$.
\end{abstract}

Keywords Dew · Evapotranspiration · Micrometeorological conditions ·

Non-rainfall water $\cdot$ Semi-arid region $\cdot$ Water respiration

\section{Introduction}

In a water-limited environment, the availability of surface water has significant effects on crop yield (Wallin 1967; Zhang and Huang 2004; Cai et al. 2011). The water transfer process in arid/ semi-arid areas exhibits unique features (Garratt and Segal 1988; Ma et al. 2005); in particular, the effect of non-rainfall water sources has been assessed in arid regions (Agam and Berliner 2006). Previous studies have reported that in arid and semi-arid areas,

Q. Zhang $\cdot$ S. Wang $(\varangle) \cdot$ F.-L. Yang $\cdot$ P. Yue $\cdot$ T. Yao $\cdot$ W.-Y. Wang

Key Laboratory of Arid Climatic Change and Disaster Reduction of Gansu

Province/Key Open Laboratory of Arid Climatic Change and Disaster

Reduction of CMA, Institute of Arid Meteorology, CMA,

Lanzhou 730020, China

e-mail: totrump@126.com

Q. Zhang

Gansu Provincial Meteorological Bureau, Lanzhou 730020, China

T. Yao - W.-Y. Wang

Lanzhou University, Lanzhou 730000, China 
dew is a common phenomenon, with days on which dew occurs being approximately $\geq 70 \%$ per year (Kabela et al. 2009; Hao et al. 2012).

Dew plays an important role in the water cycle between the air and land surface, especially in arid/semi-arid areas, while dew has significant effects on the ecological system (Monteith 1957). Research has shown that dew is a major factor that affects vegetation water-use efficiency, with a significant contribution to the plant's water economy (Ben-Asher et al. 2010). Many studies (Abraham 1996; Zangvil 1996; Jacobs et al. 2000; Wang and Zhang 2011) have reported that considerable dewfall exists in arid and semi-arid areas; the mean daily dewfall can exceed $0.1 \mathrm{~mm}$. Thus, dewfall is a major water source for vegetation survival (Zhang et al. 2007), and in several cases, the amount of dewfall can exceed that of rainfall during the same time period (Malek et al. 1999). Furthermore, Zhang et al. (2003) suggested that the phenomenon of "water respiration" from surface soil may occur in extremely arid regions, with condensation during the night and evaporation during the day.

In arid and semi-arid regions, dew collection functions as a supplementary water source. The amount of dewfall has been reported under different climate conditions. For instance, dewfall of $0.086 \mathrm{mmday}^{-1}$ was obtained with large dew collectors in India (Sharan et al. 2007), and dewfall in tropical and Mediterranean climates was recorded at 0.1 and $0.17 \mathrm{~mm} \mathrm{day}^{-1}$, respectively (Clus et al. 2008). The amount of dewfall in Croatia was recorded at $0.081 \mathrm{~mm} \mathrm{day}^{-1}$ (Beysens et al. 2007). These results indicate that dew is an important water source during the dry season.

The semi-arid areas in the Loess Plateau, China, comprise a typical loess region with a mean annual precipitation of $300-400 \mathrm{~mm}$. The water transfer processes are very different from those in arid or humid areas (Huang et al. 2008). The variability of landsurface water processes affects the rapid response of the region to land-surface heating and eco-physiological processes ( $\mathrm{Li} \mathrm{1983).} \mathrm{Zhang} \mathrm{et} \mathrm{al.} \mathrm{(2010)} \mathrm{showed} \mathrm{that} \mathrm{non-rainfall}$ water processes on the Loess Plateau are more important compared with those in other regions.

However, only preliminary studies on the land-surface moisture processes and water balance of the semi-arid Loess Plateau have been conducted (Kimura et al. 2006; Xie et al. 2006; Kimura et al. 2007). Most studies have focused on understanding the variation in soil moisture and land-surface evapotranspiration (Jacobs 1994; Jacobs and Verhoef 1997; Mohamed et al. 2004; Zhu et al. 2013). Non-rainfall processes such as dewfall have received little attention in the region. These non-rainfall processes are inadequate for use in numerical of the atmosphere models (Marshall et al. 2013) and in the estimates of the land-surface water balance. In such model simulations, soils dry too rapidly, indicating unrealistic rates of evapotranspiration (Gao et al. 2004). Therefore, a key objective in the National Natural Science Foundation of China, the "Experimental Study of Land Surface Processes in Chinese Loess Plateau (LOPEX)," was developed. LOPEX allows for the examination of dew and its role in the land-surface water balance of the Loess Plateau as one of the main study goals. LOPEX aims to increase the understanding of the mechanisms of dew formation and assess the effect of non-rainfall factors on the land-surface water balance.

The process of data collection and methodologies are described in Sect. 2. The micrometeorological conditions of dew formation and the main characteristics of dew as well as the assessment of the contribution of non-rainfall water are provided in Sect. 3, while main conclusions are presented in Sect. 4. 

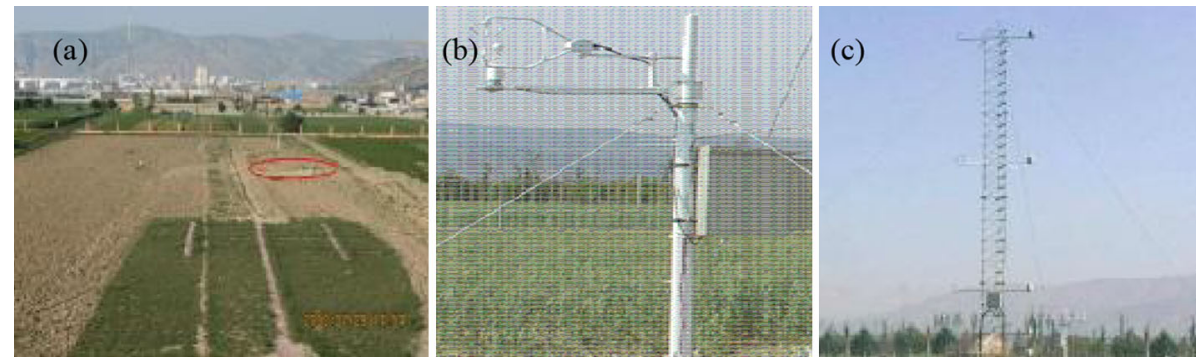

Fig. 1 Observation location (a), eddy-covariance measurement system (b), and micrometeorological tower (c)

\section{Field Experiment and Data Description}

\subsection{Site Description}

The Dingxi observation station $\left(35^{\circ} 35^{\prime} \mathrm{N}, 104^{\circ} 37^{\prime} \mathrm{E}\right.$; altitude of $\left.1986.7 \mathrm{~m}\right)$ is one of three fixed LOPEX observational sites, and is located at the junction of the Qinghai-Tibet Plateau and the Loess Plateau. This region is characterized as flat farmland without high-rise buildings or trees (Fig. 1a). It has a typical Loess Plateau geomorphology with many gullies and ridges and is dominated by a semi-arid climate with a mean annual rainfall of $386 \mathrm{~mm}$ concentrated from June to October. Pan evaporation is $1,400 \mathrm{~mm}$ per year.

\subsection{Data Processing and Instruments}

Figure 1b, c shows the observational instruments. On a 16-m high micrometeorological tower, air temperature and humidity were measured at heights of 1,2, 4, 10, and $16 \mathrm{~m}$ with Vaisala HUMICAP HMP45D sensors, and Vaisala opto-electronic anemometers (WAA151) were installed at five different heights: 1, 2, 4, 10, and $16 \mathrm{~m}$. Data, including air temperature and relative humidity, were collected every $10 \mathrm{~min}$ with a data logger (cr23x, Campbell Scientific Inc., Logan, Utah, USA). The open-path eddy-covariance system consisted of a 3D sonic anemometer (CSAT3, Campbell Scientific Inc., Logan, Utah, USA), a water vapour sensor (Li-7500, Li-COR Inc., Lincoln, Nebraska, USA), and a data logger (cr5000, Campbell Scientific Inc., Logan, Utah, USA) installed at a height of $2.5 \mathrm{~m}$ with 10-min measurement intervals. Surface and soil temperatures were measured with a probe (Model 107-L, Campbell Scientific Inc., Logan, Utah, USA) at depths of 0.05, 0.10, 0.20, 0.30, 0.50, and $0.80 \mathrm{~m}$. Soil moisture was measured with a CS616 sensor (Campbell Scientific Inc., Logan, Utah, USA) at depths of $0.1,0.2,0.3,0.5$, and $0.8 \mathrm{~m}$. Surface temperature and soil moisture data were recorded every 30 min (cr5000 data logger, Campbell Scientific Inc., Logan, Utah, USA). Land-surface actual evapotranspiration was measured with a large lysimeter with an accuracy of $0.1 \mathrm{~mm} \mathrm{~h}^{-1}$ and sensitivity of $0.01 \mathrm{~mm} \mathrm{~h}^{-1}$. The lysimeter's effective evapotranspiration area was $4.0 \mathrm{~m}^{2}$ at a depth of $2.65 \mathrm{~m}$; data were recorded every $1 \mathrm{~h}$. Spring wheat was planted in the lysimeter while ensuring that the underlying lysimeter environment is consistent with the surrounding area. The performance and accuracy parameters of the observational instruments are presented in Table 1 .

The observational data obtained during the period of June 1 2004-May 312005 are presented, daily evaporation data were calculated for a $24-\mathrm{h}$ period. For missing data, the gaps were filled by linear interpolation. The dew occurrence frequency was calculated as the 
Table 1 Experimental instruments and main technical parameters

\begin{tabular}{|c|c|c|c|c|}
\hline Instrument & Performance & Manufacturer & Height (m) & Aim \\
\hline HMP45D & $\begin{array}{l}\text { Temperature } \\
\text { measurement range, } \\
-39.2 \text { to }+60{ }^{\circ} \mathrm{C} \\
\text { with accuracy, } \pm \\
0.2^{\circ} \mathrm{C} \text {; Relative } \\
\text { humidity measuring } \\
\text { range, } 0.8-100 \% \\
\text { with accuracy, } \pm 1 \%\end{array}$ & $\begin{array}{l}\text { Vaisala, Helsinki, } \\
\text { Finland }\end{array}$ & $1,2,4,10$ and 16 & $\begin{array}{l}\text { Measuring } \\
\text { atmospheric } \\
\text { temperature and } \\
\text { relative humidity }\end{array}$ \\
\hline WAA151 & $\begin{array}{l}\text { Wind speed } \\
\text { measurement range, } \\
0.4-75 \mathrm{~m} \mathrm{~s}^{-1} \\
\text { Accuracy with } \\
\text { characteristic transfer } \\
\text { function, } \\
\pm 0.17 \mathrm{~m} \mathrm{~s}^{-2} \text { ) }\end{array}$ & $\begin{array}{l}\text { Vaisala, Helsinki, } \\
\text { Finland }\end{array}$ & $1,2,4,10$ and 16 & Measuring wind speed \\
\hline CSAT3 & $\begin{array}{l}\text { Measuring range: Wind } \\
\text { speed } 0-30 \mathrm{~m} \mathrm{~s}^{-1}, \\
\text { wind direct } \pm 170 ; \\
\text { operating } \\
\text { temperature: }-30 \text { to } \\
50^{\circ} \mathrm{C} \text {; resolving } \\
\text { capability: } u^{\prime}, v^{\prime}: 1 \\
\mathrm{~mm} \mathrm{~s}{ }^{-1} ; w^{\prime}: 0.5 \mathrm{~mm} \\
\mathrm{~s}^{-1} ; \text { accuracy: }< \pm 2 \\
\% ; \text { sampling } \\
\text { frequency: } 1-60 \mathrm{~Hz}\end{array}$ & $\begin{array}{l}\text { Campbell } \\
\text { Scientific Inc., } \\
\text { USA }\end{array}$ & 2.5 & $\begin{array}{l}\text { Measuring sensible } \\
\text { and latent heat } \\
\text { fluxes with Li-7500 }\end{array}$ \\
\hline $\mathrm{Li}-7500$ & $\begin{array}{l}\text { Sampling frequency: } 5 \text {, } \\
10 \text { or } 20 \mathrm{~Hz} \text {; } \\
\text { operating } \\
\text { temperature: }-25 \text { to } \\
50{ }^{\circ} \mathrm{C}\end{array}$ & LI-COR Co., USA & 2.5 & $\begin{array}{l}\text { Measuring latent heat } \\
\text { flux }\end{array}$ \\
\hline $107-\mathrm{L}$ & $\begin{array}{l}\text { Measuring range: }-35 \\
\text { to } 50{ }^{\circ} \mathrm{C} \text {; accuracy: } \\
\pm 0.2{ }^{\circ} \mathrm{C}\end{array}$ & $\begin{array}{l}\text { Campbell } \\
\text { Scientific Inc., } \\
\text { USA }\end{array}$ & $\begin{array}{l}0,0.05,0.10,0.20 \\
0.30,0.50 \text { and } \\
0.80 \text { under the } \\
\text { soil }\end{array}$ & $\begin{array}{l}\text { Measuring } \\
\text { temperature }\end{array}$ \\
\hline CS616 & $\begin{array}{l}\text { Accuracy: } \pm 2.5 \% \\
\text { Volumetric Water } \\
\text { Content (VWC) } \\
\text { using standard } \\
\text { calibratio }\end{array}$ & $\begin{array}{l}\text { Campbell } \\
\text { Scientific Inc., } \\
\text { USA }\end{array}$ & $\begin{array}{l}0.10,0.20,0.30 \\
0.50,0.80 \text { under } \\
\text { the soil }\end{array}$ & $\begin{array}{l}\text { Measuring soil water } \\
\text { content }\end{array}$ \\
\hline LG-I lysimeter & $\begin{array}{l}\text { Accuracy: } 0.03 \mathrm{~mm} ; \\
\text { sensitivity: } 0.01 \mathrm{~mm}\end{array}$ & $\begin{array}{l}\text { Institute of Arid } \\
\text { Meteorology, } \\
\text { China }\end{array}$ & Surface & $\begin{array}{l}\text { Measuring dew, fog, } \\
\text { non-rainfall water } \\
\text { and evaporation }\end{array}$ \\
\hline
\end{tabular}

dew occurrence ratio of actual to possible times. For example, at 0500 local time, during the 10-day observation period, when three dew days occur, then the frequency at $050030 \%$.

\subsection{Methods of Estimating Non-rainfall Water}

Fog, dew (or frost), and soil-absorbed water were estimated from the large weighing lysimeter; micrometeorological data were regarded as the discriminating factor. Soil-adsorption water is defined as the water vapour in air directly absorbed by the soil. The method of discriminating fog, dew and soil adsorption has been set forth previously (Zhang et al. 2010), where fog, dew 
(or frost), and soil adsorption water were distinguished according to different atmospheric physical conditions based on micrometeorological data. A large weighing lysimeter was utilized to directly measure the instantaneous weight (denoted by $f$ ) of the surface material and its variation $\left(\Delta f_{i}\right)$ within the lysimeter; negative $\Delta f_{i}$ indicates a decrease in the material and vice versa. Therefore, in a given period, evapotranspiration $(E)$ is the accumulation of instantaneous evapotranspiration observations calculated as

$$
E=\sum \Delta f_{i}
$$

if $\Delta f<0$. A positive $\Delta f_{i}$ indicates that the instantaneous mass of the lysimeter is increasing and the lysimeter gains mass from several possible sources. The first is precipitation $P_{\mathrm{r}}$, which can be expressed as

$$
P_{\mathrm{r}}=\sum \Delta f_{i}
$$

if $\Delta f>0$ and precipitation or non-rainfall exists. The second source is dry deposition $\left(P_{\mathrm{d}}\right)$, which can be expressed as

$$
P_{\mathrm{d}}=\sum \Delta f_{i}
$$

if $\Delta f>0$ and dust accumulation exists. The positive component of $\Delta f_{i}$ includes carbon absorbed by plants and soil; however, this amount is negligible. In this study, the data for dust days were eliminated because the magnitude of dry deposition is unknown.

The positive $\Delta f_{i}$ values are more important for our study because these values contain non-rainfall information from the atmosphere, which can be obtained by excluding data related to precipitation and dust storm processes. The values corresponding to fog, $W_{\mathrm{f}}$, dew (or frost), $W_{\mathrm{d}}$, and soil-absorbed water, $W_{\mathrm{a}}$,were derived. The water supply from fog, $W_{\mathrm{f}}$, can only occur in the saturated near-surface atmosphere and is expressed as

$$
W_{\mathrm{f}}=\sum \Delta f_{i}
$$

if $\Delta f>0$, relative humidity $(R H)=100 \%$, and no precipitation or dust exists.

In Eq. 4 , dew (or frost), $W_{d}$, can only appear when the surface temperature is lower than the dew point (or frost point) and if the surface layer of the atmosphere is not saturated, and is expressed as

$$
W_{\mathrm{d}}=\sum \Delta f_{i}
$$

if $\Delta f>0, R H<100 \%, T_{\mathrm{S}}<T_{\mathrm{D}}$, and no precipitation or dust exists. In Eq. $5, T_{\mathrm{S}}$ is the surface temperature and $T_{\mathrm{D}}$ is the dew point (or frost point).

Soil-absorbed water $W_{\mathrm{a}}$ can only appear when the surface temperature is higher than the dew point (or frost point) and the surface layer of the atmosphere is not saturated. It is expressed as

$$
W_{\mathrm{a}}=\sum \Delta f_{i},
$$

if $\Delta f>0, R H<100 \%, T_{\mathrm{S}}>T_{\mathrm{D}}$, and no precipitation or dust exists. 

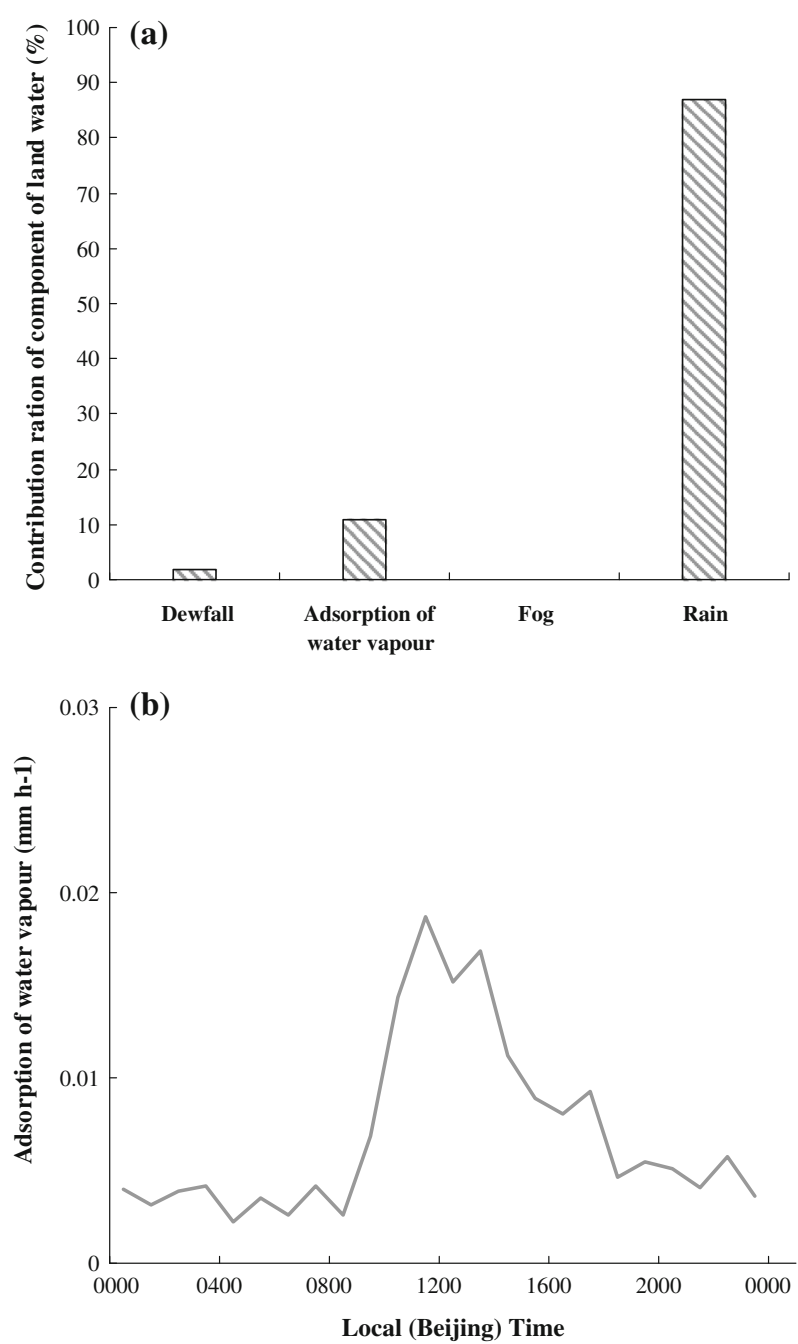

Fig. 2 Water source contributions from precipitation, dew, fog, and adsorption of water vapour (a), and the mean diurnal cycle of vapour adsorption during the study period (June 1 2004-May 31 2005) (b)

\section{Results and Discussion}

\subsection{Characteristics of the Land-Surface Water Balance}

Aside from the precipitation in semi-arid areas, we also assessed the contributions of nonrainfall water sources, such as dew, fog, and soil adsorption water. The ratios of their annual cumulative values to the sum of these water sources were utilized to present the contributions (Fig. 2a). As expected, precipitation is the dominant water source, $87 \%$, in the study area, while soil adsorption contributes $11 \%$ to the total surface water resource, followed by the dew contribution of approximately $2 \%$. The contribution from fog is negligible. Non-precipitation surface water accounts for $13 \%$ of the total surface water source, and the combined effect of these water sources influences the calculation of the surface water budget. Figure $2 b$ shows 

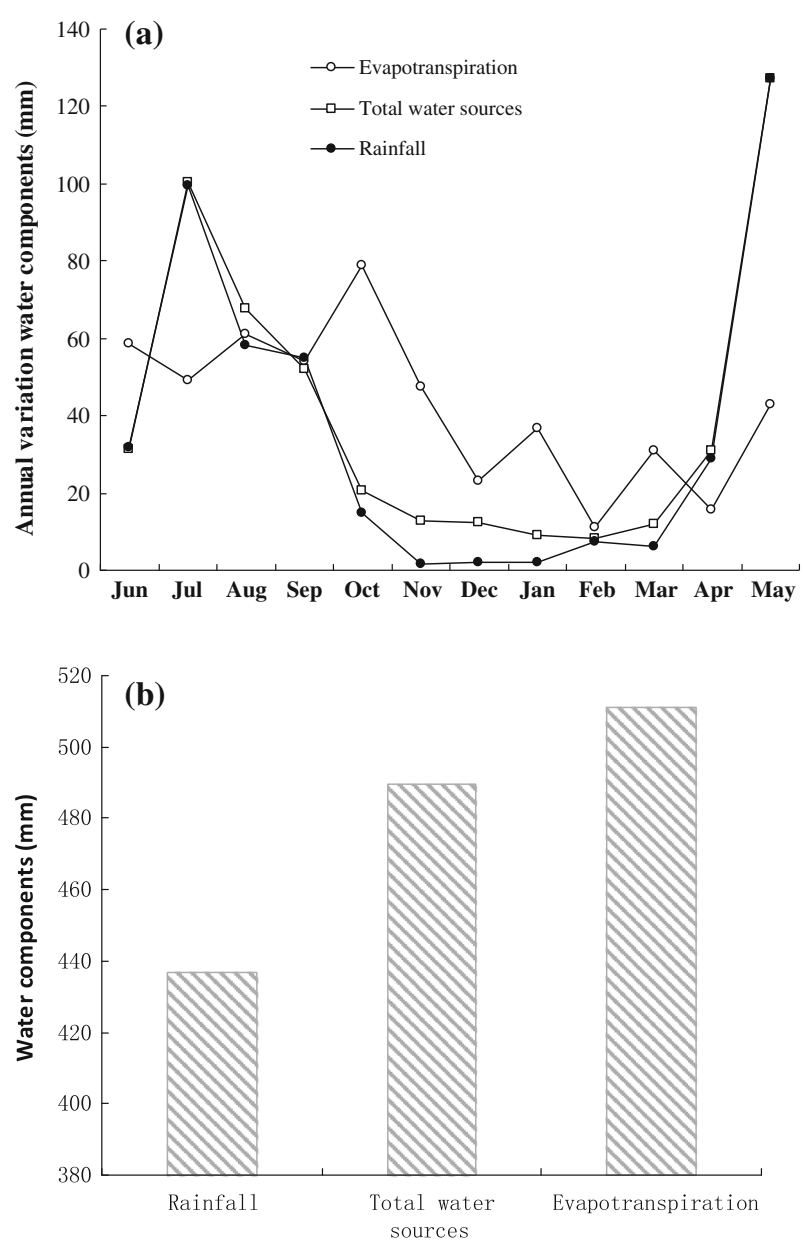

Fig. 3 Annual variation in the land-surface hydrological budget (a), and cumulative values of each component (b). Total water source is the sum of precipitation, dew, and adsorption

the diurnal variation in adsorption water based on data from June 12004 to May 31 2005; soil adsorption occurred mainly during the daytime, as found by Verhoef et al. (2006). However, the duration in the Loess Plateau reported herein is longer than that reported by Verhoef et al. (2006). The peak value of adsorption is $0.02 \mathrm{~mm} \mathrm{~h}^{-1}$, which is smaller compared with the value obtained by Verhoef et al. (2006) of $0.02-0.10 \mathrm{~mm} \mathrm{~h}^{-1}$. Soil adsorption also occurs during the night through the values are very small.

Rainfall and non-rainfall processes were considered when the surface moisture budget was balanced (Fig. 3). Rainfall was considered separate from the other factors because no run-off or infiltration occurred in the lysimeter system; thus, evapotranspiration should be roughly equivalent to the long-term precipitation in humid areas. In absolute values, the common form of the land-surface water balance equation can be expressed as

$$
E=P,
$$

where $E$ is evapotranspiration and $P$ is precipitation. However, the ratio of non-rainfall water to precipitation is larger in arid and semi-arid areas than that in humid areas. Thus, the non- 


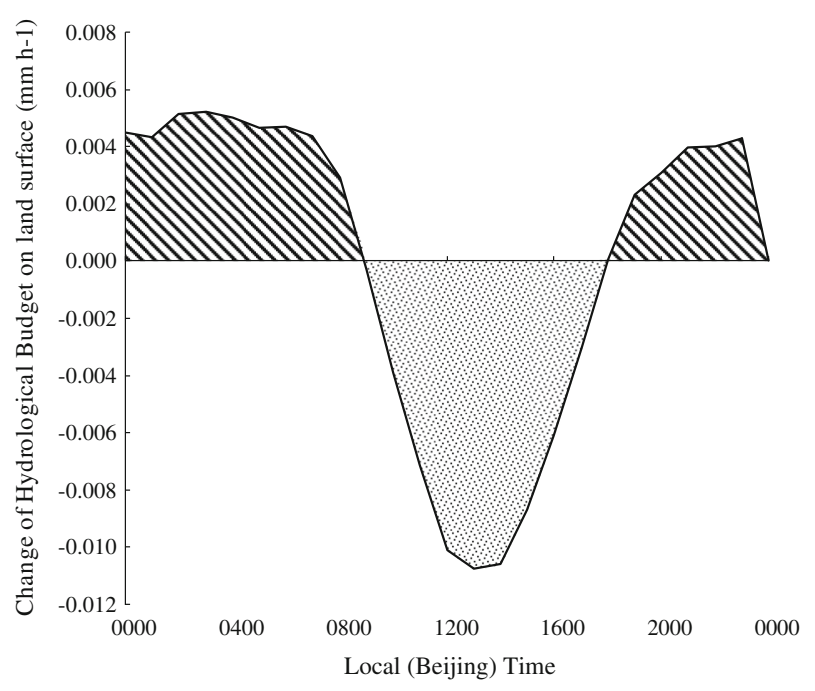

Fig. 4 Diurnal variations in mean the land-surface water budget on precipitation free days

rainfall water sources, $W_{\mathrm{d}}, W_{\mathrm{a}}$, and $W_{\mathrm{f}}$, should be included in Eq. 7. The improved equation can be expressed as

$$
E=P+\left(W_{\mathrm{d}}+W_{\mathrm{a}}+W_{\mathrm{f}}\right),
$$

and Fig. 3a shows the annual variation in the land-surface hydrological balance, where a notable imbalance exists between evapotranspiration and precipitation. Figure $3 \mathrm{~b}$ shows the mean annual value of rainfall $(437 \mathrm{~mm})$, total land-surface water sources $(489 \mathrm{~mm})$, and evapotranspiration $(511 \mathrm{~mm})$ measured by the lysimeter. The inclusion of non-rainfall water sources reduces the imbalance in the surface hydrological budget from 74 to $22 \mathrm{~mm}$. This result suggests that the contribution of non-rainfall water should not be ignored.

To understand the role of the non-rainfall water sources, we removed the precipitation data in the analysis of the daily water-balance variation. The land-surface water-balance characteristics behaved like a "respiration process" during diurnal variations (Fig. 4). The "inhalation process" occurred when the soil obtained moisture from condensation and soil adsorption during the night; the "expiration process" occurred when soil moisture was consumed by evapotranspiration during the day. The water obtained during the night was $0.06 \mathrm{~mm}$, and the amount of water consumed during the day was $0.058 \mathrm{~mm}$. These two measurements are roughly equivalent and thus confirm the assumption of Zhang and Huang (2004) in the analysis of soil moisture profiles in semi-arid regions.

\subsection{Characteristics of Dew and Meteorological Factors}

\subsubsection{Overview of Published Dew Observations}

The amount of dew per day at the different sites is shown in Table 2, where amounts in most regions range from 0.1 to $0.2 \mathrm{~mm}_{\text {day }}{ }^{-1}$; the amount reaches $0.2 \mathrm{~mm} \mathrm{day}^{-1}$ at the Dingxi station. We assumed in our calculations that all observation errors are similar. However, obvious differences were observed in the different regions (Table 2). In the USA, the maximum dewfall can reach $0.8 \mathrm{~mm} \mathrm{day}^{-1}$ (Kabela et al. 2009), but this may be an overestimation because 
Table 2 The amount of dew at different sites

\begin{tabular}{llll}
\hline Site & Underlying surface & Dewfall $\left(\mathrm{mm} \mathrm{h}^{-1}\right)$ & Reference \\
\hline Goshute Valley & Shrubs & 0.0032 & Malek et al. (1999) \\
Castle Dale & Alfalfa & 0.0038 & Malek et al. (1999) \\
Negev highland & Rock & $0.0058-0.012$ & Kidron (2000) \\
Western Negev, Israel & Sand & $0.0038-0.013$ & Jacobs et al. (2000) \\
Nizzana, Israel & Sand & $0.0042-0.013$ & Jacobs et al. (2000) \\
Negev highland, Israel & Rock & $0.005-0.01$ & Kidron (2000) \\
Gaolan, China & Gravel & 0.0029 & Li (2002) \\
Gaolan, China & Fine sand & 0.005 & Li (2002) \\
Gaolan, China & Loess soil & 0.0063 & Li (2002) \\
Netherlands & Grassland & 0.0042 & Jacobs et al. (2006) \\
Guangzhou, China & City & $0.0005-0.0014$ & Ye et al. (2007) \\
Rambla Honda, Spain & Shrub & 0.003 & Moro et al. (2007) \\
Iowa, USA & Corn & $0.0004-0.025$ & Kabela et al. (2009) \\
Iowa, USA & Soybean & $0.0001-0.03$ & Kabela et al. (2009) \\
Gurbantunggut, China & Sand & $0.0025-0.005$ & Zhang et al. (2009) \\
Dingxi, China & Loess soil & 0.008 & Wang and Zhang (2011) \\
\hline
\end{tabular}

this value is almost equal to a small rainfall episode. The minimum dew level is $0.013-0.034$ $\mathrm{mm}$ in Guangzhou, China. No significant difference was observed in the amount of dew at different underlying surfaces, a result in agreement with that of Kidron (2010), suggesting that dew formation is closely related to local micrometeorological conditions.

\subsubsection{Dew on the Loess Plateau and Relevant Meteorological Factors}

The formation of dew is highly sensitive to variations in micrometeorological conditions, such as local temperature, humidity, and wind speed. Awareness of the micrometeorological conditions favourable for dew formation in the semi-arid region of the Loess Plateau is important.

The micrometeorological conditions most closely related to dew (or frost) formation include the surface temperature, relative humidity, and surface-layer wind speed. Surface relative humidity should be greater than $60 \%$ in the semi-arid area of the Loess Plateau, a condition likely to occur with the increase in relative humidity in the surface layer. When relative humidity $>80 \%$, the frequency of dew (or frost) occurrence reached $50 \%$. The relationship between dew (or frost) and the difference in air temperature and wind speed at the surface layer is more complex.

When the temperature difference between heights of 1 and $4 \mathrm{~m}$ was in the range of $0.2-$ $0.4 \mathrm{~K}$, the frequency of dew occurrence peaked at $40 \%$, and declined for strong and weak inversions. These conditions improve the possibility of reaching the dew (or frost) formation threshold. When the surface layer exhibited neutral or unstable stratification, dew (or frost) frequency was at its minimum of $5 \%$. Furthermore, the frequency of dew (or frost) occurrence was high when the wind speed at $1 \mathrm{~m}$ was between 1 and $1.5 \mathrm{~m} \mathrm{~s}^{-1}$. The frequency of dew occurrence decreased to below $5 \%$ when the wind speed was $<0.4$ or $>1.9 \mathrm{~m} \mathrm{~s}^{-1}$.

The characteristics of the above relationships can be explained. The greater the surface layer's relative humidity is, the easier is the formation of dew. Nevertheless, wind speed and 


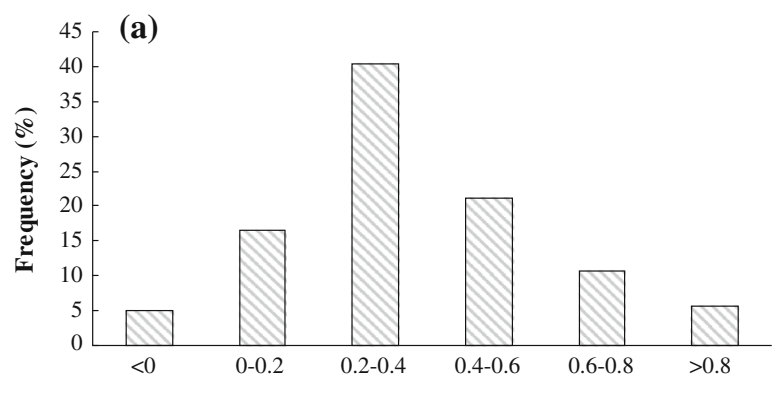

(4m-1m) temperature difference $(K)$
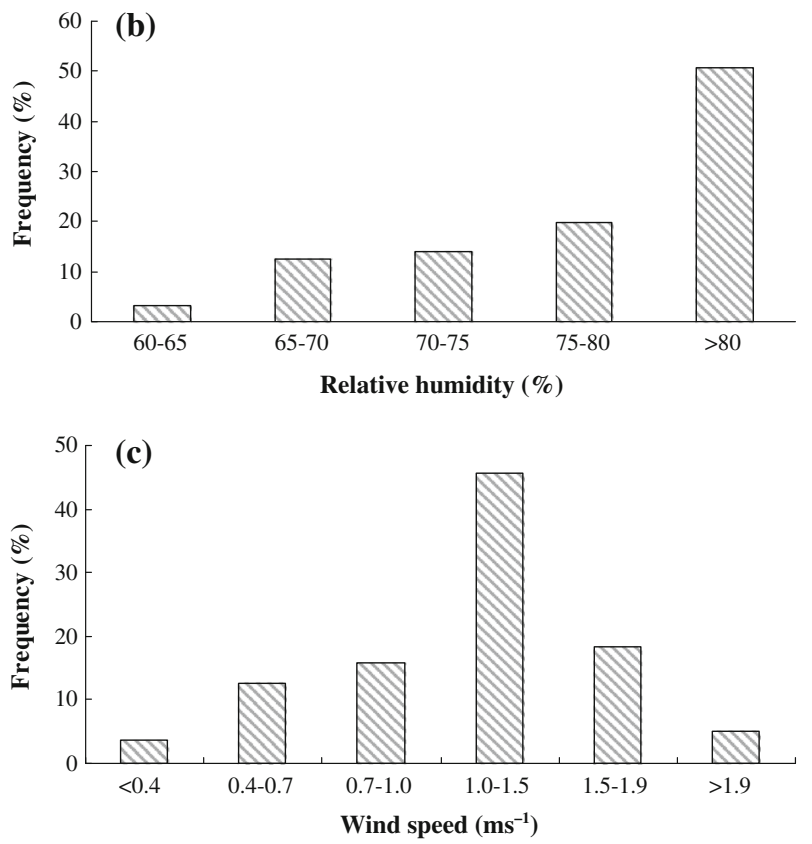

Fig. 5 Relationships between dewfall (frost) frequency and (a) temperature differences between heights of 4 and $1 \mathrm{~m},(\mathbf{b})$ relative humidity, and (c) wind speed. The unit of frequency is \%

temperature affect dew formation in a complex manner, and too large or small a wind speed is unfavourable for the exchange of water vapour. Similarly, the dewpoint temperature is difficult to attain under the weak inversion. However, if the inversion is too strong, water vapour exchange would be negatively affected (Clus et al. 2009). Therefore, the combination of moderate inversion and wind speed provides an optimal state of surface-layer atmospheric turbulent diffusion, where water vapour is continuously supplemented through turbulent transport. Simultaneously, sufficient stability is generated to ensure that a low surface temperature is maintained at night. According to Jacobs et al. (2006), the Penman-Monteith equation can be expressed as

$$
\lambda_{\mathrm{v}} E=\left(\frac{s}{s+\gamma}\right)\left(Q_{*}-G\right)+\left(\frac{\gamma}{s+\gamma}\right) \frac{\rho \lambda_{\mathrm{v}} \delta q}{r_{\mathrm{av}}},
$$



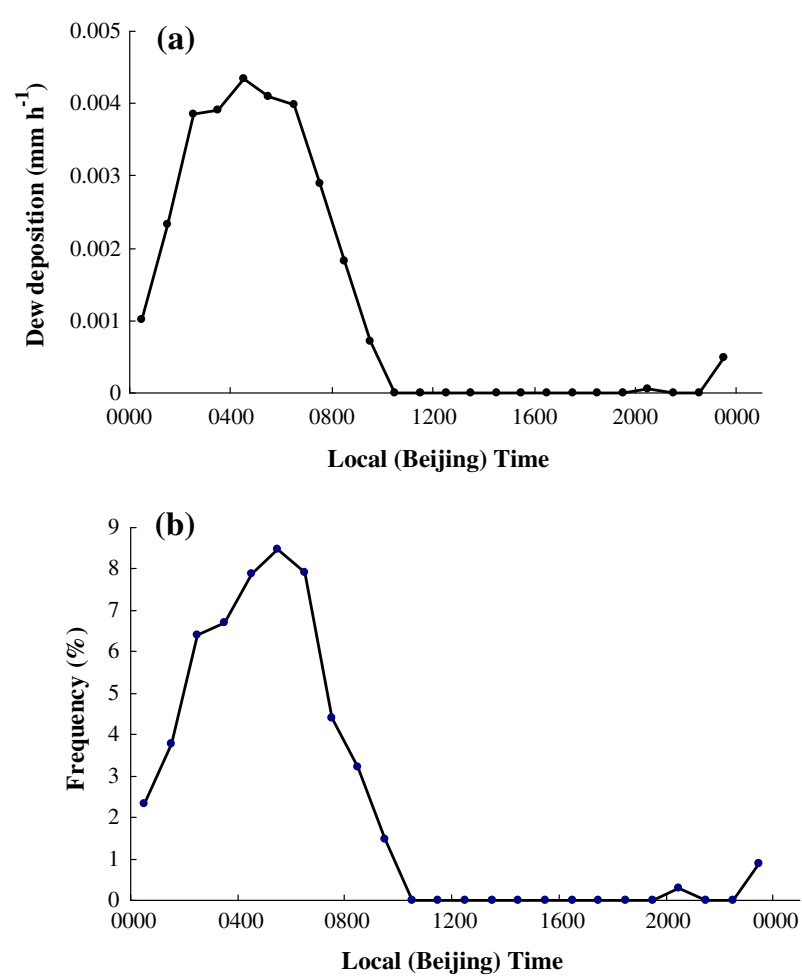

Fig. 6 Diurnal variation in dew deposition (a) and frequency (b) from June 2004 to May 2005

where $E$ is evaportranspiration or dewfall, $\lambda_{\mathrm{V}}$ is the latent heat of vaporization, $s$ is the slope of the saturation specific humidity curve, $\gamma$ is the psychrometric constant, $Q_{*}$ is the net radiation, $G$ is soil heat flux, $\rho$ is air density, $r_{\mathrm{av}}$ is the aerodynamic resistance to vapour transport, and $\delta q$ is the specific humidity deficit at the reference level. The non-linear relationship between air temperature and specific humidity results in a non-linear variation in the deficit term, the second term on the right. Hence, dew does not always increase with the increase of temperature (Fig. 5a). In the humidity term, a decreasing $\delta q$ for increasing relative humidity results in a small deficit term; thus, dew fall increases (Fig. 5b). From the aerodynamic resistance perspective, a non-linear relationship also exists between aerodynamic resistance and wind speed, and this relationship results in a non-linear fluctuation in the deficit term. Therefore, condensation is restricted by either high or low wind speeds (Fig. 5c).

The dew (or frost) amount exhibits diurnal and seasonal variations, with dewfall higher during the night than during the day (Fig. 6a). The maximum dewfall is approximately $0.0045 \mathrm{~mm} \mathrm{hr}^{-1}$ at about $0500 \mathrm{~h}$ and decreases rapidly after this time because of increased surface evaporation. The variation in dewfall frequency is similar to that in amount (Fig. 6b); the frequency of dewfall occurrence increases from midnight to $0500 \mathrm{~h}$ then decreases. The maximum frequency reached $9 \%$ during the night. These results are similar to those obtained by Kabela et al. (2009) for Ames, USA.

Figure 7 shows the seasonal variations in dewfall (or frost) and frequency of occurrence (Fig. 7a, b, respectively), where dewfall is highest in autumn $(3.6 \mathrm{~mm})$, followed by spring $(2.4 \mathrm{~mm})$. The lowest amount is in summer and winter, approximately $2 \mathrm{~mm}$. These amounts 

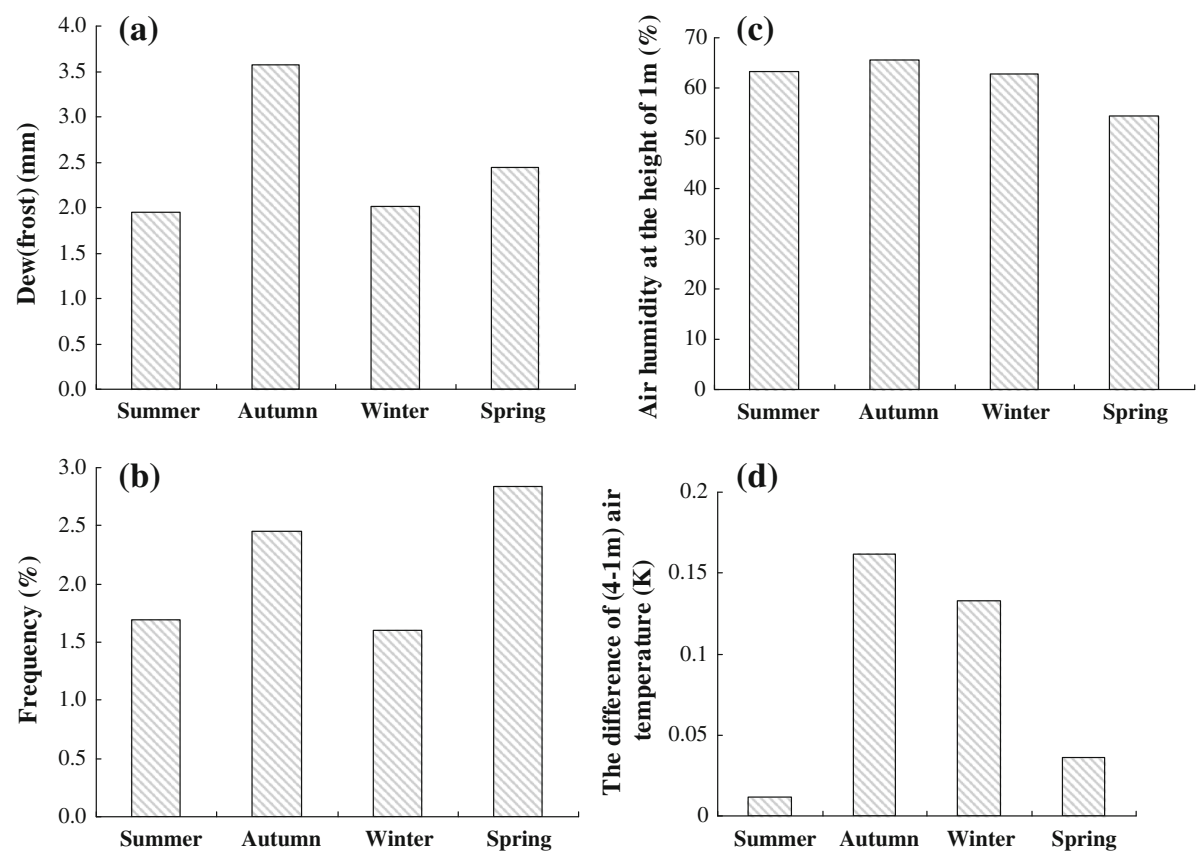

Fig. 7 Comparison of seasonal dew (frost) (a), frequency (b), air humidity of $1 \mathrm{~m}(\mathbf{c})$, and difference in (4-1) $\mathrm{m}$ air temperature $(\mathbf{d})$ at DingXi station

are comparable to a moderate rainfall event in semi-arid areas. This phenomenon is related to seasonal air humidity and air temperature. Figure $7 \mathrm{c}, \mathrm{d}$ shows the differences in air temperature and humidity at heights of 1-4 m, with autumn exhibiting the largest difference during the year. This result shows that autumn has favourable meteorological conditions, consistent with the findings for the Loess Plateau (Wang and Zhang 2011). The water vapour content in winter, summer, and spring is similar to that during autumn; however, the air temperature difference is small and thus indicates weak radiation cooling (Clus et al. 2009; Kidron 2010). Therefore, dewfall is relatively small. This indicates close relationships between dewfall and meteorological conditions on both diurnal and seasonal scales. The frequency of occurrence of dew (or frost) exhibits different seasonal variations, with the highest values during spring of $2.8 \%$, the second highest in autumn of $2.4 \%$, and lowest values of 1.7 and $1.6 \%$ in winter and summer, respectively. The relatively low surface temperatures and high atmospheric moisture conditions during spring and autumn facilitate dew formation. The amount of dew is higher in autumn compared with that in spring in the semi-arid areas of the Loess Plateau, mainly because of higher water vapour content in autumn following the summer monsoon (Chen et al. 2005).

Figure 8 shows the influence of precipitation and cloudiness on dewfall (frost). The dew (or frost) amount is highest on the first day after a rainfall event, followed by that on the day preceding the rainfall event, and is very small during other periods. According to Eq. 9, on the first day after rainfall, the sky is clear with high net radiation. Concurrently, soil heat flux is larger than that on a rainfall day but still smaller than that on the second day after a rainfall event. Therefore, the available energy $\left(Q_{*}-G\right)$ is extremely large, and results in very high dewfall. On the second day after a rainfall event, the surface become dry, resulting in a large soil heat flux and causing the saturation deficit to become large, leading to low 

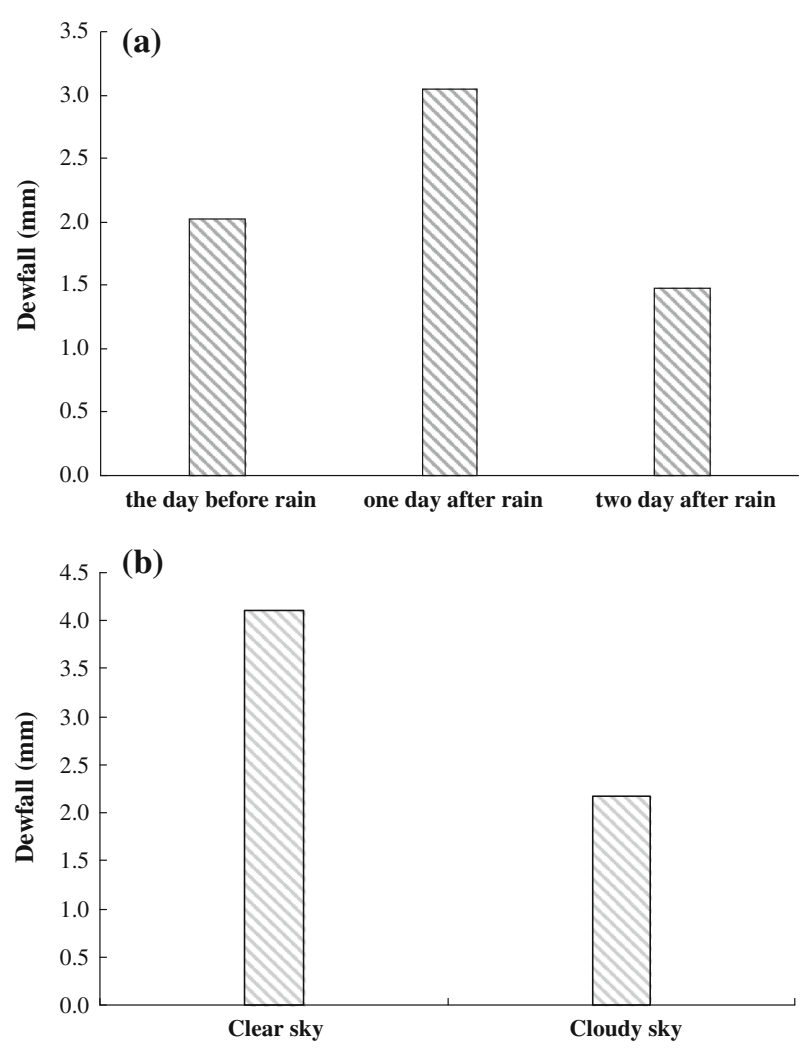

Fig. 8 Influence of the precipitation process (a) and cloudiness (b) on dew (or frost)

dewfall. Dewfall on clear days is greater than that on cloudy days because surface radiative cooling at night is stronger on clear days than on cloudy days (Fig. 8b).

\section{Conclusions}

The land-surface water characteristics of the semi-arid Loess Plateau are very different from those in extremely arid or humid areas. In this region, precipitation is still the dominant water source; non-rainfall surface water accounts for approximately $15 \%$ of the total land-surface water source. Therefore, this water source should not be ignored. Among the non-rainfall land surface water sources, soil adsorption water is the highest, followed by dewfall. Non-rainfall water is thus important to the land -surface water balance in arid and semi-arid areas.

Dewfall (or frost) is influenced by micrometeorological conditions, and increases with an increase in the relative humidity of the surface layer. Dewfall (or frost) is highest for an inversion of $0.25 \mathrm{~K}$ and surface wind speed of $1.5 \mathrm{~m} \mathrm{~s}^{-1}$. Dewfall (or frost) is highest on the first day after a rainfall event but declines significantly over the subsequent days. Furthermore, dewfall is largest in autumn, followed by that in spring, with the lowest amounts in summer and winter.

We found that non-rainfall water sources are important to the surface water budget in the semi-arid areas of Loess Plateau, China. During diurnal variations, the land-surface water 
balance is characterized by a respiration process because of the important contribution from non-rainfall water. The maximum probability of dew formation in the areas of the Loess Plateau occurs overnight between 2000 and 1000 local time.

Our study provides new information on land-surface water processes in the semi-arid areas of the Loess Plateau. However, the measurement techniques or methods for non-rainfall water still need improvement. For example, it is thought that the measurement evaportion by large lysimeter is reliable. But in fact, the soil in a lysimeter dries more rapidly than that outside the lysimeter after rainfall. This generates a bias between measured and true values over an observational area.

Acknowledgments This work was supported by the National Natural Science Foundation of China (40830957, 41075009, and 31300376), the National Key Basic Research Program of China (2013CB430206), and the National Special Meteorological Scientific Research Fund in the Public Welfare of China (GYHY200806021). The authors would like to thank Yang Xingguo and Wang Runyuan for assisting in the data collection. Gratitude is also extended to Prof. Huqiang Zhang (Bureau of Meteorology, Melbourne, Victoria, Australia) for his help in improving the manuscript. Lastly, the authors thank the two reviewers for their detailed comments.

Open Access This article is distributed under the terms of the Creative Commons Attribution License which permits any use, distribution, and reproduction in any medium, provided the original author(s) and the source are credited.

\section{References}

Abraham Z (1996) Six years of dew observation in the Negev Desert Israel. J Arid Environ 32:361-371

Agam N, Berliner PR (2006) Dew formation and water-vapour adsorption in semi-arid environments-a review. J Arid Environ 65:572-590

Ben-Asher J, Alpert P, Ben-Zvi A (2010) Dew is a major factor affecting vegetation water use efficiency rather than a source of water in the eastern Mediterranean area. Water Resour Res 46:W10532

Beysens D, Clus O, Mileta M, Milimouk I, Muselli M, Nikolayeva VS (2007) Collecting dew as a water source on small islands: the dew equipment for water project in Bisevo (Croatia). Energy 32:1032-1037

Cai XM, Yang YC, Ringler C, Zhao JS, You LZ (2011) Agricultural water productivity assessment for the Yellow River Basin. Agr Water Manag 98:1297-1306

Clus O, Ortega P, Muselli M, Milimouk I, Beysensal D (2008) Study of dew water collection in humid tropical islands. J Hydrol 361:159-171

Clus O, Ouazzani J, Muselli M, Nikolayev VS, Sharan G, Beysens D (2009) Comparison of various radiationcooled dew condensers using computational fluid dynamics. Desalination 249:707-712

Chen YH, Huang JP, Chen CH, Zhang Q, Feng JD, Jing HC, Wang TH (2005) Temporal and spatial distributions of cloud water resources over northwestern China. Plate Meteorol 24(6):905-912

Gao ZQ, Chae N, Kim J, Hong J, Choi T, Lee H (2004) Modeling of surface energy partitioning, surface temperature, and soil wetness in the Tibetan prairie using the Simple Biosphere Model 2 (SiB2). J Geophys Res 109:D06102

Garratt JR, Segal M (1988) On the contribution of atmospheric moisture to dew formation. Boundary-Layer Meteorol 45(3):209-236

Hao XM, Li C, Guo B, Ma JX, Ayupa M, Chen ZS (2012) Dew formation and its long-term trend in a desert riparian forest ecosystem on the eastern edge of the Taklimakan Desert in China. J Hydrol 472473(23):90-98

Huang JP, Zhang W, Zuo JQ, Bi JR, Shi JS, Wang X, Chang ZL, Huang ZW, Yang S, Zhang BD, Wang GY, Feng GH, Yuang JY, Zhang L, Zuo HC, Wang SG, Fu CB, Chou JF (2008) An overview of the semi-arid climate and environment research observatory over the Loess Plateau. Adv Atmos Sci 25:906-921

Jacobs AFG (1994) Dew formation and the drying process within a maize canopy. Boundary-Layer Meteorol 69:367-378

Jacobs AFG, Verhoef A (1997) Soil evaporation from sparse natural vegetation estimated from Sherwood numbers. J Hydrol 188-189:443-452

Jacobs AFG, Heusinkveld BG, Berkowicz SM (2000) Dew measurements along a longitudinal sand dune transect, Negev Desert, Israel. Int J Biometeorol 43:184-190 
Jacobs AFG, Heusinkveld BG, Wichink Kruit RJ, Berkowicz SM (2006) Contribution of dew to the water budget of a grassland area in the Netherlands. Water Resour Res 42:W03415

Kabela ED, Hornbuckle BK, Cosh MH, Anderson MC, Gleason ML (2009) Dew frequency, duration, amount, and distribution in corn and soybean during SMEX05. Agric For Meteorol 149:11-24

Kidron GJ (2000) Analysis of dew precipitation in three habitats within a small arid drainage basin, Negev Highlands, Israel. Atmos Res 55:257-270

Kidron GJ (2010) The effect of substrate properties, size, position, sheltering and shading on dew: and experimental approach in the Negev Desert. Atmos Res 98:378-386

Kimura R, Fan J, Zhang X, Takayama N, Kamichika M, Matsuok N (2006) Evapotranspiration over the grassland field in the liudaogou basin of the Loess Plateau. Acta Oecol 29:45-53

Kimura R, Bai L, Fan J, Takayama N, Hinokidani O (2007) Evapotranspiration estimation over the river basin of the Loess Plateau of China based on remote sensing. J Arid Environ 68:53-65

Li XY (2002) Effects of gravel and sand mulches on dew deposition in the semiarid region of China. J Hydrol 260:151-160

Li YS (1983) The properties of water cycle in soil and their effect on water cycle for land in the loess region. Acta Ecol Sin 3(2):91-101

Ma ZG, Huang G, Gan WQ, Chen ML (2005) Multi-scale temporal characteristics of the dryness/wetness over northern China during the last century. Chin J Atmos Sci 29(5):671-681

Malek E, McCurdy GD, Giles B (1999) Dew contribution to the annual water balance in semi-arid desert valleys. J Arid Environ 42:71-80

Marshall M, Tu K, Funk C, Michaelsen J, Williams P, Williams C, Ardö J, Boucher M, Cappelaere B, de Grandcourt A, Nickless A, Nouvellon Y, Scholes R, Kutsch W (2013) Improving operational land surface model canopy evapotranspiration in Africa using a direct remote sensing approach. Hydrol Earth Syst Sci 17:1079-1091

Mohamed YA, Bastiaanssen WGM, Savenijea HHG (2004) Spatial variability of evaporation and moisture storage in the swamps of the upper Nile studied by remote sensing techniques. J Hydrol 289:145-164

Monteith JL (1957) Dew. Q J R Meteorol Soc 83:322-341

Moro MJ, Were A, Villagarcia L, Cantón Y, Domingo F (2007) Dew measurement by eddy covariance and wetness sensor in a semiarid ecosystem of SE Spain. J Hydrol 335:295-302

Sharan G, Beysens D, Milimouk-Melnytchouk I (2007) A study of dew water yields on Galvanized iron roofs in Kothara (North-West India). J Arid Environ 69:259-269

Verhoef A, Diaz-Espejo A, Knight JR, Villagarcia L, Fernandez JE (2006) Adsorption of water vapour by bare soil in an olive grove in southern Spain. J Hydrometeorol 7:1011-1027

Wallin JR (1967) Agrometeorological aspects of dew. Agric Meteorol 4:85-102

Wang S, Zhang Q (2011) Atmospheric physical characteristics of dew formation in semi-arid in Loess Plateau. Acta Phys Sin 60(5):059203

Xie ZK, Wang YJ, Jiang WL, Wei XH (2006) Evaporation and evapotranspiration in a watermelon field mulched with gravel of different sizes in northwest China. Agric Water Manag 8:173-184

Ye YH, Zhou K, Song LY, Jin JH (2007) Dew amounts and its correlations with meteorological factors in urban landscapes of Guangzhou, China. Atmos Res 86:21-29

Zangvil A (1996) Six years of dew observation in the NegevDesert, Israel. J Arid Environ 32:361-371

Zhang J, Zhang YM, Downing A, Cheng JH, Zhou XB, Zhang BC (2009) The influence of biological soil crusts on dew deposition in Gurbantunggut Desert, northwestern China. J Hydrol 379:220-228

Zhang Q, Huang RH (2004) Water vapor exchange between soil and atmosphere over a gobi surface near an oasis in summer. J Appl Meteorol 43(12):1917-1928

Zhang Q, Wei GA, Huang RH (2003) Characteristics of hydrologic transfer between soil and atmosphere over gobi near oasis at the end of Summer. Adv Atmos Sci 20(3):442-452

Zhang Q, Wang S, Zeng J (2010) On the non-rained land-surface water components and their relationship with soil moisture content in Arid Region. Arid Zone Res 27(3):392-400

Zhang SL, Lars L, Harald G (2007) Modeling the effects of mulching and fallow cropping on water balance in the Chinese Loess Plateau. Soil Tillage Res 93:283-298

Zhu G, Su YH, Li X, Zhang K, Li CB (2013) Estimating actual evapotranspiration from an alpine grassland on Qinghai-Tibetan plateau using a two-source model and parameter uncertainty analysis by Bayesian approach. J Hydrol 476:42-51 